\title{
Accumulation of F-Spondin in Injured Peripheral Nerve Promotes the Outgrowth of Sensory Axons
}

\author{
Tal Burstyn-Cohen, ${ }^{1}$ Ayala Frumkin, ${ }^{1}$ Yi-Tian Xu, ${ }^{2}$ Steven S. Scherer, ${ }^{2}$ and Avihu Klar ${ }^{1}$ \\ ${ }^{1}$ Department of Anatomy and Cell Biology, The Hebrew University-Hadassah Medical School, Jerusalem, 91120 Israel, \\ and ${ }^{2}$ Department of Neurology, The University of Pennsy/vania, Philadelphia, Pennsylvania 19104-6077
}

\begin{abstract}
F-spondin, an extracellular matrix protein, is present in peripheral nerve during embryonic development, but its amount diminishes by birth. Axotomy of adult rat sciatic nerve, however, causes a massive upregulation of both F-spondin mRNA and protein distal to the lesion. F-spondin in the distal stump of axotomized nerve promotes neurite outgrowth of sensory neu-
\end{abstract}

rons, as revealed by protein neutralization with F-spondinspecific antibodies. Thus, F-spondin is likely to play a role in promoting axonal regeneration after nerve injury.

Key words: nerve regeneration; neurite outgrowth; Schwann cells; extracellular matrix; F-spondin; sensory axons
Injury to a peripheral nerve initiates a sequence of characteristic changes in a distal position to the injury site that is termed Wallerian degeneration (for review, see Fawcett and Keynes, 1990). During the first few days after axotomy, axons fragment and disappear, and their myelin sheaths break up and are phagocytosed by invading macrophages. Schwann cells proliferate and remain within their basal laminae, forming the so-called Schwann tubes into which axons regenerate (Ramon y Cajal, 1928). Schwann cells that were previously myelinating dramatically decrease their synthesis of myelin-related protein and glycolipids and begin expressing cell adhesion molecules (CAMs) such as neural CAM (N-CAM), L1, and N-cadherin (for review, see Scherer and Salzer, 1996). These phenotypic changes in Schwann cells probably promote axonal regeneration, because these cell adhesion molecules support neurite outgrowth, whereas myelin contains factors that inhibit nerve regeneration (Schwab, 1990).

We have previously isolated a novel floor plate gene, $F$-spondin, which encodes an extracellular matrix (ECM) protein with adhesive properties (Klar et al., 1992a,b). As shown in Figure 1, $F$-spondin encodes a secreted molecule of 807 amino acids (aa). The carboxyl half of the protein (440-807) contains six thrombospondin-type 1 repeats (TSRs) (Lawler and Hynes, 1986; Bornstein et al., 1991). The amino half is composed of two domains. Amino acids 1-200 share homology with the amino terminal portion of reelin, a protein implicated in guiding the migration of cortical neuroblasts (D'Arcangelo et al., 1995). Amino acids 200-440 form the spondin domain and share homology with a new protein family, the mindins, which are secreted molecules that bind to the ECM and contain the spondin domain

\footnotetext{
Received June 8, 1998; revised July 31, 1998; accepted Aug. 11, 1998.

This work was supported by grants to A.K. from the Israel Cancer Research Foundation, The Israel USA Binational Foundation, the Israel Science Foundation, and Cambridge Neuroscience. S.S.S. was supported by grants from National Institutes of Health. We thank Marc Tessier-Lavigne for fruitful discussions; Shlomo Rotshenker and Chaya Kalcheim for fruitful discussions and for comments on this manuscript; Joel Israeli and Eran Blauground for comments on this manuscript; Michael Tal and Fanny Reichart for technical assistance in preparing the sciatic nerve sections for the outgrowth assay; and Boaz Gillo and Chaya Kalcheim for sharing equipment.

Correspondence should be addressed to Dr. Avihu Klar, Department of Anatomy and Cell Biology, The Hebrew University-Hadassah Medical School, P.O. Box 12272, Jerusalem, 91120 Israel.

Copyright (C) 1998 Society for Neuroscience $\quad 0270-6474 / 98 / 188875-11 \$ 05.00 / 0$
}

as well as a TSR domain [Higashijima et al. (1997); Umemiya et al. (1997); Y. Feinstein and A. Klar (unpublished results)].

We have shown previously that recombinant F-spondin promotes neural cell adhesion and neurite extension in vitro, suggesting that it might play a role in axonal growth and guidance in the developing CNS and PNS. Consistent with this notion, $F$-spondin mRNA is expressed by embryonic Schwann cells during the period when motor and sensory axons project to their peripheral targets (Klar et al., 1992a). In the current study, we demonstrate that F-spondin protein is present in peripheral nerve during embryonic development, but its amount diminishes by birth. Axotomy of the adult sciatic nerve, however, causes a massive upregulation of F-spondin mRNA and protein distal to the lesion. In addition, F-spondin protein is associated with the ECM. By using blocking antibodies, we demonstrate that the endogenous F-spondin in cryostat sections of a distal stump of axotomized nerve is involved in promoting the outgrowth of embryonic sensory neurons. Thus, F-spondin may play a significant role in axonal regeneration in the PNS.

\section{MATERIALS AND METHODS}

DNA constructs. To generate the pR2 plasmid (for expressing aa 571807), a PstI fragment containing this region was subcloned into the pQE-32 vector (Qiagen, Hilden, Germany). To generate the pR5 plasmid (for expressing aa 238-440), the fragment between a BamHI site (aa 238) and the oligonucleotide GAGAGATCTAGGGGTGTCATCTTCATC (aa 440) was subcloned into the BamHI sites of pGEX vector. To generate the F-spondin-His expression vector (pSecF-spo-His), a pair of PCR primers, GCAAGCTTGCGCTCGCTTTCTCGGATG (aa 27) and CGTCTAGAGAACTGCTCTCCATCTGAC (aa 752), were used. The PCR fragment was inserted into the HindIII and $X b a \mathrm{I}$ sites of pSecTagB (Invitrogen, San Diego, CA). To generate the reelin-His domain expression vector (pSecF-reel-His), a pair of PCR primers, CGTCTAGACTTGGCAGTTCCGCAGGC (aa 206) and aa 27, were used. The PCR fragment was inserted into the HindIII and XbaI sites of pSecTagB (Invitrogen).

Production of $R 2$ and $R 5$ antibodies. The $\mathrm{pR} 2$ and $\mathrm{pR} 5$ plasmids were introduced into Escherichia coli, the expression of the proteins was induced by isopropyl $\beta$-D-thiogalactopyranoside, and the recombinant proteins were purified by adsorption on a column of glutathione-agarose beads (Sigma, St. Louis, MO) or Ni-nitrilo-tri-acetic acid (Qiagen), respectively, according to the manufacturer's directions. The purified proteins were injected into rabbits $(250 \mu \mathrm{g}$ of protein/injection in adjuvant; total of three injections), and the sera were tested for immunore- 
activity on Western blots and immunohistochemistry on Bouin's-fixed transverse sections of embryonic tissue.

In situ hybridization. For whole-mount in situ hybridization, embryonic day 11 (E11) rat embryos were fixed in $3.7 \%$ formaldehyde in $0.1 \mathrm{M}$ 3-[N-morpholino]propanesulfonic acid, $2 \mathrm{mM}$ EGTA, $1 \mathrm{mM} \mathrm{MgSO}_{4}$, for $2 \mathrm{hr}$, followed by in situ hybridization as described (Harland, 1991), with a few modifications: anti-digoxygenin antibody (Boehringer Mannheim, Indianapolis, IN) was preadsorbed with $1 \%$ E14 rat acetone powder (Harlow and Lane, 1988) before the addition to the hybridization mixture. The chromogenic reaction was performed for 1-2 hr. Frozen sections of these whole mounts were collected and mounted on glass slides.

In situ hybridization with $\left[{ }^{35} \mathrm{~S}\right] \mathrm{UTP}$-labeled single-stranded antisense RNA probes was performed as described previously (Wilkinson et al., 1987), using a T3 or T7 RNA polymerase. We used probes that encompass part of the $3^{\prime}$ untranslated region of F-spondin cDNA [nucleotide (nt) 3359-4029] or the TSRs (nt 1545-2626). Exposure times ranged from 4 to $14 \mathrm{~d}$. Sense probes were used as controls.

Schwann cell culture. Schwann cells were isolated from 3-d-old rat pups by the method of Brockes et al. (1979) and expanded on $10 \mathrm{~cm}$ plates coated with poly-L-lysine (PLL) in DMEM supplemented with $10 \%$ fetal calf serum (FCS), a crude extract of glial growth factor from bovine pituitaries (Brockes et al., 1980), and $2 \mu \mathrm{M}$ forskolin (Porter et al., 1986). The cells were passaged three times, grown to confluence, and then switched to one of the following media for $3 \mathrm{~d}$ : (1) DMEM $+10 \%$ FCS or (2) DMEM + $10 \%$ FCS supplemented with $4 \mu \mathrm{M}$ forskolin. All of the cultures used in these experiments were essentially pure cultures of Schwann cells, as judged by staining for p75/NGF receptor (NGFR) (data not shown).

Sciatic fibroblasts were cultured from the perineurium obtained during the dissection of the nerves. They were cultured in DMEM $+10 \%$ FCS, initially on uncoated plastic plates to which Schwann cells did not adhere. Then they were passaged three times onto PLL-coated plates and grown under conditions identical to those of the Schwann cells before RNA extraction.

Collection of tissues. Using aseptic technique, the sciatic nerves of anesthetized (50 mg/kg pentobarbital, i.p.), adult (10-13 weeks old) Sprague Dawley rats were exposed at the sciatic notch. Some nerves were doubly ligated and transected with iridectomy scissors, and the two nerve stumps were sutured at least $1 \mathrm{~cm}$ apart; this technique prevents axonal regeneration to the distal nerve stump for at least 2 months. Nerve crush was produced by tightly compressing the sciatic nerve at the sciatic notch with flattened forceps twice, each time for $10 \mathrm{sec}$; this technique causes all of the axons to degenerate but allows axonal regeneration. At varying times after nerve injury, the animals were killed by $\mathrm{CO}_{2}$ inhalation, the distal nerve stumps were removed, and the most proximal 2-3 $\mathrm{mm}$ were trimmed off. For transected nerves, the entire distal nerve stump was taken from just below the lesion to the ankle $(\sim 4 \mathrm{~cm}$ long). For crushed nerves, the distal nerve stump was divided into two equal segments, termed the proximal and distal segments, each $\sim 2 \mathrm{~cm}$ long. For Northern blot analysis, the nerves were immediately frozen in liquid nitrogen and stored at $-80^{\circ} \mathrm{C}$. For immunohistochemistry, nerves were placed immediately into fixative. All animal protocols were approved by the Institutional Animal Care and Use Committee of The University of Pennsylvania.

Northern blotting. RNA was isolated from rat sciatic nerves and Schwann cells by $\mathrm{CsCl}_{2}$ gradient centrifugation (Chirgwin et al., 1979). Equal samples $(10 \mu \mathrm{g})$ of total RNA were electrophoresed in 1\% agarose, $2.2 \mathrm{M}$ formaldehyde gels, transferred to nylon membranes (Duralon, Stratagene, La Jolla, CA) in $6 \times \mathrm{SSC}$, and UV cross-linked $(0.12 \mathrm{~J})$. Blots were prehybridized, hybridized, and washed using standard techniques; the final stringency of the wash was $0.2 \times \mathrm{SSC}$ at $65^{\circ} \mathrm{C}$ for $30 \mathrm{~min}$ (Sambrook et al., 1989). The following cDNAs were used as probes: a 294 bp of mouse thrombospondin-type 1 (Lawler and Hynes, 1986), a $1.1 \mathrm{~kb}$ fragment of rat GAP-43 (Karns et al., 1987), a $0.7 \mathrm{~kb}$ BamHI fragment of rat NGFR (Radeke et al., 1987), a full-length cDNA of rat $\mathrm{P}_{0}$ (Lemke and Axel, 1985), and a full-length cDNA of glyceraldehyde 3-phosphate dehydrogenase (GAPDH) (Fort et al., 1985). Plasmid inserts were isolated after restriction endonuclease digestion, separated by agarose gel electrophoresis, and purified by electroelution. ${ }^{32} \mathrm{P}$-labeled cDNA probes with specific activities of $2-5 \times 10^{9} \mathrm{cpm} / \mu \mathrm{g}$ were prepared by primer extension with random hexamers using the Prim-a-gene kit (Promega, Madison, WI) according to the manufacturer's instructions.

Immunohistochemistry. Rat embryos at the designated stages, and sciatic nerves at the specified times after transection, were fixed in
Bouin's fixative. Tissues were dehydrated and embedded in paraffin or infiltrated with sucrose and embedded in OCT. Sections ( $7 \mu \mathrm{m}$ thick) were cut, mounted on Superfrost Plus (Fisher Scientific, Houston, TX) slides, rehydrated, blocked for at least $1 \mathrm{hr}$ (5\% goat serum in PBS), and incubated overnight in a humidified chamber at $4^{\circ} \mathrm{C}$ with a $1: 1000$ dilution of the appropriate antiserum diluted in blocking solution. The sections were washed two times in PBS, incubated with FITC-, tetramethylrhodamine B isothiocyanate (TRITC)-, or Cy-2-conjugated donkey or goat anti-rabbit IgG (Jackson ImmunoResearch, West Grove, PA) (diluted 1:200 in blocking solution) in a humid chamber for $2 \mathrm{hr}$ at room temperature, rinsed twice in PBS, mounted in Fluoromount, and examined by indirect immunofluorescence on a Zeiss Axiovert or a Leica DMR microscope.

Transfection and purification of F-spondin-His protein. Human embryonic kidney (HEK) 293 cells were maintained in DMEM 10\% fetal calf serum and transfected with pSecF-spo-HIS using a modified calcium phosphate method. For each $10 \mathrm{~cm}$ plate of subconfluent (30\% confluent) cells, $1 \mathrm{ml}$ of a solution containing $0.5 \mathrm{ml}$ of $0.1 \times$ Tris EDTA, pH 8, 0.45 $\mathrm{ml}$ of $2 \times \mathrm{HBS}, \mathrm{pH} 7.15,4 \mu \mathrm{g}$ of plasmid DNA, and $0.05 \mathrm{ml}$ of $2.5 \mathrm{M}$ $\mathrm{CaCl}_{2}$ was added to the growth media. After $14 \mathrm{hr}$, the plates were washed once with PBS, and $10 \mathrm{ml}$ of growth media was added. After 12-18 hr the medium was changed to $5 \mathrm{ml} /$ plate of OPTI-MEM. Conditioned medium was collected after 4-8 d. Agarose-Talon ( $2 \mathrm{ml}$; Clontech, Cambridge, UK) was added to $40 \mathrm{ml}$ of conditioned media, and the protein was purified according to the manufacturer's protocol. The fractions that contained the purified protein were supplemented with $\mathrm{NaCl}$ to a final concentration of $1 \mathrm{M}$. The positive fractions were concentrated on Centrisart (Sartorius). Ovomocoid (OVO; $1 \mathrm{mg} / \mathrm{ml}$ final concentration) was added, and fractions were snap-frozen in liquid nitrogen in $50 \mu$ l aliquots.

Neurite outgrowth assays. The dorsal root ganglia (DRGs) of E14 rat spinal cords were dissected and incubated with $0.025 \mathrm{mg} / \mathrm{ml}$ trypsin (Life Technologies, Gaithersburg, MD) for $20 \mathrm{~min}$ in a $\mathrm{Ca}^{2+} / \mathrm{Mg}^{2+}$-free modified essential medium (S-MEM; Life Technologies) supplemented with $8 \mathrm{mg} / \mathrm{ml}$ glucose. The tissue was then washed with S-MEM, triturated to a single-cell suspension, and plated at a density of 2500 cells/well in 96-well dishes on appropriate substrates, in Ham's F12 medium (Life Technologies) supplemented with N3 (F12-N3) (Romijin et al., 1982), 50 $\mathrm{ng} / \mathrm{ml}$ NGF (Promega), and placed in a $5 \% \mathrm{CO}_{2}$ humidified incubator at $37^{\circ} \mathrm{C}$. Dorsal root ganglia were dissected from E14 rats, dissociated as described above, and plated with F12-N3 supplemented with $50 \mathrm{ng} / \mathrm{ml}$ NGF at a density of $4 \times 10^{4}$ cells $/ 3 \mathrm{~cm}$ dish.

F-spondin-His was affinity-purified on a Talon affinity column (Clontech). Affinity-purified F-spondin-His $(12-25 \mu \mathrm{g} / \mathrm{ml})$ was absorbed onto nitrocellulose (Lemmon et al., 1989). The nitrocellulose was then blocked with bovine serum albumin (BSA; $30 \mathrm{mg} / \mathrm{ml}$ ), which provided a further control for background neurite outgrowth. Control substrates, each incubated for 1-2 $\mathrm{hr}$, were prepared as follows: $10 \mathrm{mg} / \mathrm{ml} \mathrm{BSA}$ (Amresco) in PBS; $20 \mu \mathrm{g} / \mathrm{ml}$ poly-D-lysine (Sigma) followed by $20 \mu \mathrm{g} / \mathrm{ml}$ laminin (Sigma) and $1 \mathrm{mg} / \mathrm{ml}$ ovomucoid (Sigma). E14 DRG neurons were plated on immobilized protein substrates at a density of 2500 cells/well (of a 96-well plate) and grown for $14 \mathrm{hr}$. Cultures were then fixed in $4 \%$ paraformaldehyde, permeabilized with $0.1 \%$ Triton X-100, and stained using monoclonal antibody (mAb) 3A10 (Furley et al., 1990), (available from Developmental Studies Hybridoma Bank, University of Iowa), which recognizes a neuronal filament-associated protein and serves as a marker for fine neurites. Neuronal cell bodies and neurites were visualized by indirect immunofluorescence on a Zeiss Axioplan microscope. Neurite lengths were measured as the distance from the edge of the soma (sharply defined by 3A10 fluorescence) to the tip of its longest neurite. Neurite lengths were measured only if the entire length of the neurite could be unambiguously identified. If no neurite was identified, the neurite length was arbitrarily considered to be $10 \mu \mathrm{m}$. Statistical analysis was preformed by the JMP program.

Adhesion assay. Dissociated E14 DRG cells were plated on immobilized protein substrate at a density of 200,000 cells $/ 35 \mathrm{~mm}$ tissue culture dish (35 mm diameter) (Nunc, Naperville, IL). After $1 \mathrm{hr}$ the cultures were washed twice with PBS and fixed in $4 \%$ paraformaldehyde. Ten independent counts were taken from each experiment.

DRG outgrowth assay on cryosections of lesioned sciatic nerves. Adult rat sciatic nerves were transected to prevent axonal regeneration. Three weeks later the animals were anesthetized, and the distal nerve stumps and peritoneum were aseptically removed and placed in L-15 medium (Biological Industries, Kibbutz Beit Haemek, Israel). The distal stump was cut into $5 \mathrm{~mm}$ segments, which were aligned in rows and sandwiched 

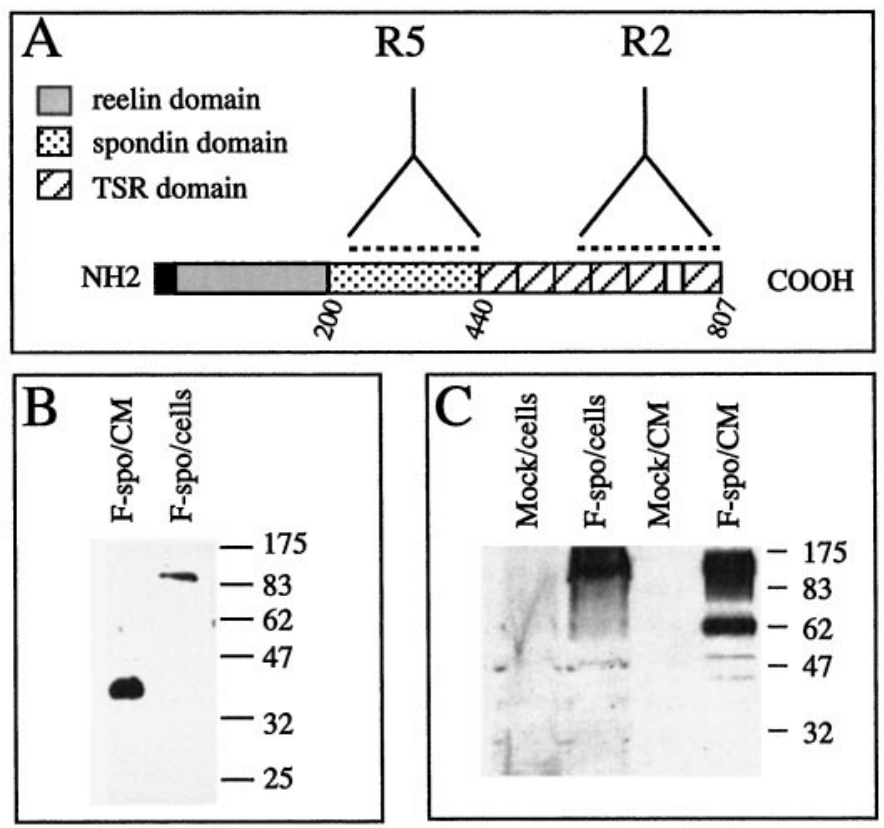

Figure 1. Transfected HEK 293 cells secrete processed forms of F-spondin protein. $A$, Schematic representation of the F-spondin domain structure. The black box represents the signal sequence; the gray box represents the reelin domain; the dotted box represents the spondin domain; and the hatched boxes represent the thrombospondin-type 1 repeats (TSR). The broken lines represent the regions used to generate the R2 and R5 Abs. B, Western blot analysis of F-spondin in transfected HEK 293 cells, with the R2 Ab. A $115 \mathrm{kDa}$ protein is present in the cell lysate (cells), and a $40 \mathrm{kDa}$ protein is present in the conditioned media $(C M) . C$, Western blot analysis of F-spondin in transfected HEK 293 cells, with the $\mathrm{R} 5 \mathrm{Ab}$. A $115 \mathrm{kDa}$ protein is present in the cell lysate (cells), and a $60 \mathrm{kDa}$ protein is present in the conditioned media $(C M)$.

between two pieces of peritoneum. The peritoneum prevented contact between the nerve segments and the OCT embedding medium during sectioning and subsequent processing. This sandwich was held together with insect pins, frozen in liquid nitrogen, and kept at $-70^{\circ} \mathrm{C}$ until sectioned at $10 \mu \mathrm{m}$ on a cryostat. Sections were collected on poly-Dlysine-coated sterilized glass coverslides, allowed to dry for a maximum of $1 \mathrm{hr}$ at room temperature, covered with a minimum volume $(\sim 30 \mu \mathrm{l})$ of DMEM, and placed in a humid chamber in a $5 \% \mathrm{CO}_{2}, 37^{\circ} \mathrm{C}$ incubator (Tuttle and Matthew, 1991).

Rat E14 DRGs were collected into ice-cold L-15 medium, and 10-15 DRGs were placed over the previously prepared cryosections in a minimal volume of F12 medium supplemented with the following: $10 \mathrm{~mm}$ glucose (Life Technologies-BRL), 2 mm Glutamax-I Supplement (Life Technologies-BRL), MEM vitamins, N3 supplement (Romijin et al., 1982), penicillin + streptomycin, and $50 \mathrm{ng} / \mathrm{ml} \mathrm{NGF} \mathrm{(Promega).} \mathrm{Purified}$ $\mathrm{IgG}$ fractions of $\mathrm{R} 2$ and $\mathrm{R} 5$ as well as control rabbit antisera were added to a final concentration of 50 or $100 \mu \mathrm{g} / \mathrm{ml}$. After $48 \mathrm{hr}$, the DRGs were fixed in $4 \%$ paraformaldehyde at room temperature for $20-30 \mathrm{~min}$, washed with PHTX (PBS, $1 \%$ heat-inactivated goat serum, $1 \%$ Triton $\mathrm{X}-100$ ), and stored at $4^{\circ} \mathrm{C}$ until immunostaining. Coverslips were incubated with $3 \mathrm{~A} 10 \mathrm{mAb}$ overnight at $4^{\circ} \mathrm{C}$ with gentle agitation, washed with PHTX, and incubated with the FITC-conjugated goat anti-mouse IgG secondary antibody overnight at $4^{\circ} \mathrm{C}$ with gentle agitation. Coverslips were then washed in PHTX, mounted with Fluoromount, and visualized by indirect immunofluorescence on a Zeiss Axiovert microscope.

\section{RESULTS}

\section{Domain-specific antibodies recognize processed fragments of F-spondin}

To examine the relationship between the structure and function of F-spondin, as well as its in vivo localization, we generated rabbit antibodies (Abs) against different domains of the protein.
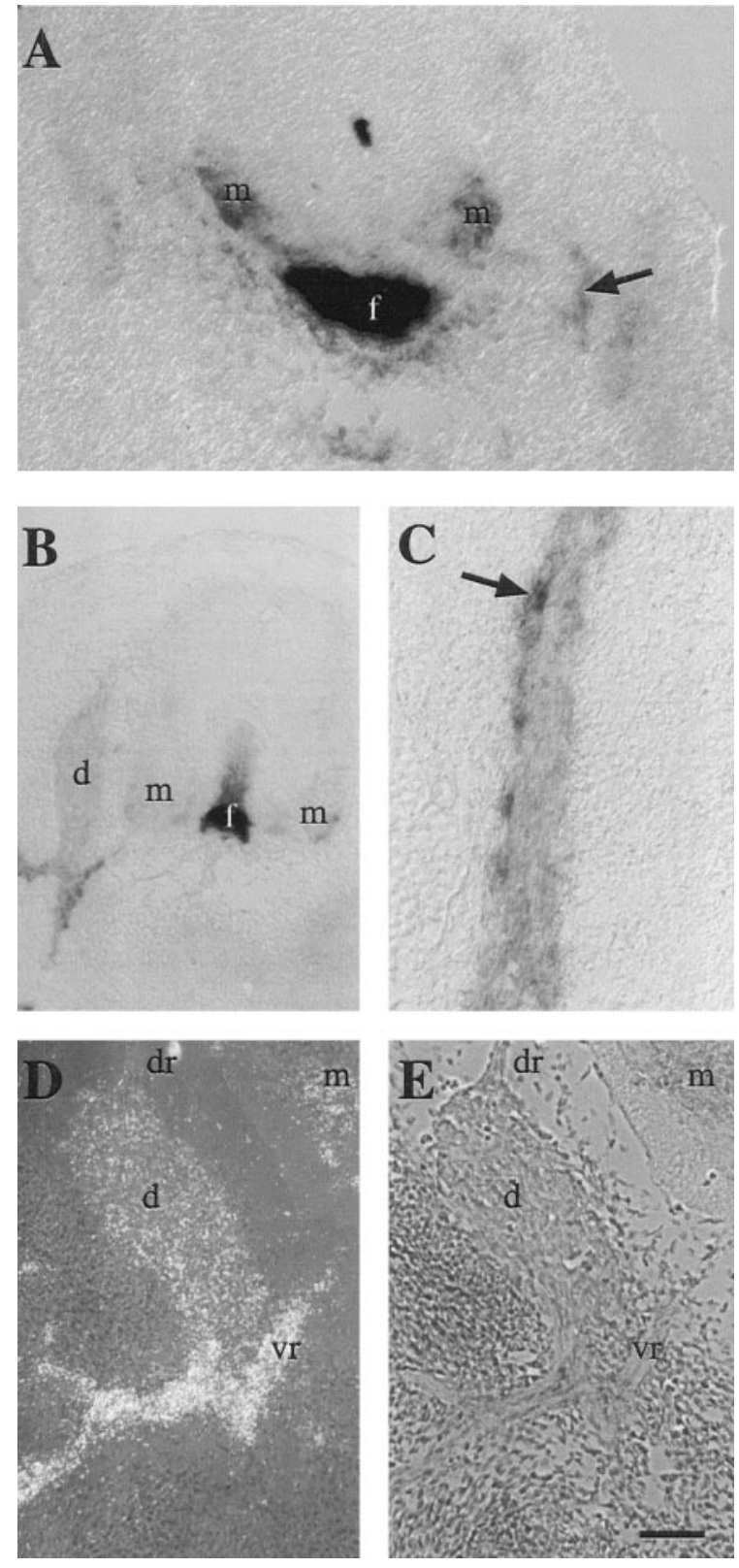

Figure 2. Localization of F-spondin mRNA in the developing rat nervous system by using digoxigenin-labeled $(A-C)$ or radiolabeled $(D)$ antisense probes. $A$, At E11, signal is detected in the floor plate, the ventral horn, the mesenchyme that surrounds the ventral spinal cord, and along the nerve roots (arrow). Scale bar, $50 \mu \mathrm{m}$. B. At E13, signal is detected in the floor plate, the DRG, and along the nerve roots. Scale bar, $100 \mu \mathrm{m}$. $C$, At E13, signal is detected in cells (arrow) within peripheral nerve. Scale bar, $25 \mu \mathrm{m} . D, E$, At E15, signal is detected in the DRG and associated ventral roots; no expression is detected along the dorsal roots (arrow) in the dark-field micrograph $(D)$. E, Bright-field micrograph of $D$. Scale bar, $75 \mu \mathrm{m}$. $f$, Floor plate; $m$, motor neurons; $d$, DRG; $d r$, dorsal root; $v r$, ventral root.

As shown in Figure 1, the R2 Ab was raised against the TSR domains 3-6 (aa 572-807), and the R5 Ab was raised against the spondin domain (aa 238-440).

We showed previously that COS cells expressing a myc-tagged, recombinant F-spondin secrete a $115 \mathrm{kDa}$ protein that binds to the ECM (Klar et al., 1992a). The R2 and R5 Abs also recognized the $115 \mathrm{kDa}$ F-spondin expressed both by transfected COS cells (data not shown) and by HEK 293 cells, as determined by 

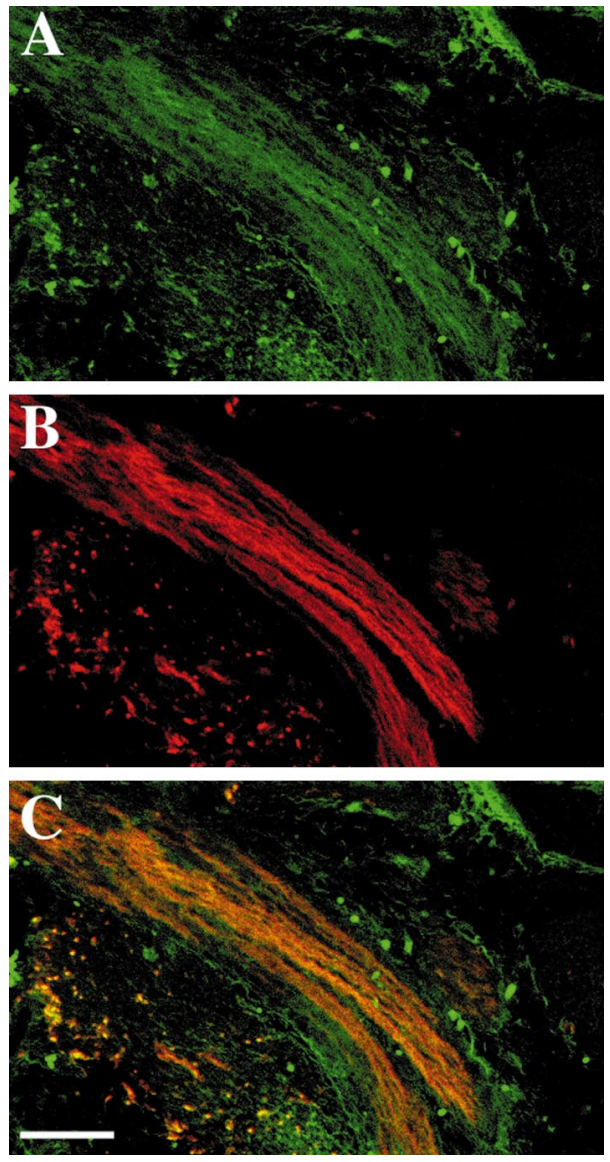

Figure 3. F-spondin protein accumulates in peripheral nerve and adjacent mesenchyme. $A, \mathrm{E} 15$ rat peripheral nerve immunolabeled with the R5 antibody (FITC). $B$, The same section as $A$ immunolabeled with the HNK-1 mAb (TRITC). $C$, Overlap of R5 (FITC) and HNK-1 (TRITC). F-spondin protein is colocalized with HNK-1 within the nerve and is also detected around it.

Western blotting (Fig. 1B,C). These Abs also stained live transfected COS and HEK 293 cells (data not shown), indicating that in both cell types F-spondin is translated and secreted as a 115 $\mathrm{kDa}$ protein that is likely bound to the ECM. An additional step of proteolytic processing occurs only in the conditioned media of HEK 293 cells. Using the R2 and R5 Abs, we have detected 40 $\mathrm{kDa}$ (Fig. 1B, lane 1) and $60 \mathrm{kDa}$ (Fig. 1C, lane 4) fragments of F-spondin, respectively. The molecular weight of these regions corresponds with the TSR domain $(40 \mathrm{kDa})$ and the reelin/ spondin domain $(60 \mathrm{kDa})$. The difference in processing of F-spondin in HEK 293 and COS cells may reflect the presence of protease, which is expressed only in HEK 293 cells. Alternatively, COS cells may express an inhibitor to the putative protease.

\section{F-spondin mRNA and protein are localized in embryonic peripheral nerve}

To compare the distribution and timing of F-spondin mRNA and protein expression, we first localized its mRNA by in situ hybridization in rat embryos. Motor axons begin to grow into the periphery at E11, when the highest levels of $F$-spondin mRNA are seen in the floor plate (Klar et al., 1992a). Lower levels of $F$-spondin mRNA were detected in ventral horn motor neurons, in the mesenchyme surrounding the ventral spinal cord, and along the ventral roots and peripheral nerves (Fig. $2 A$ ). In the ventral horn, $F$-spondin mRNA expression was restricted to the brachial
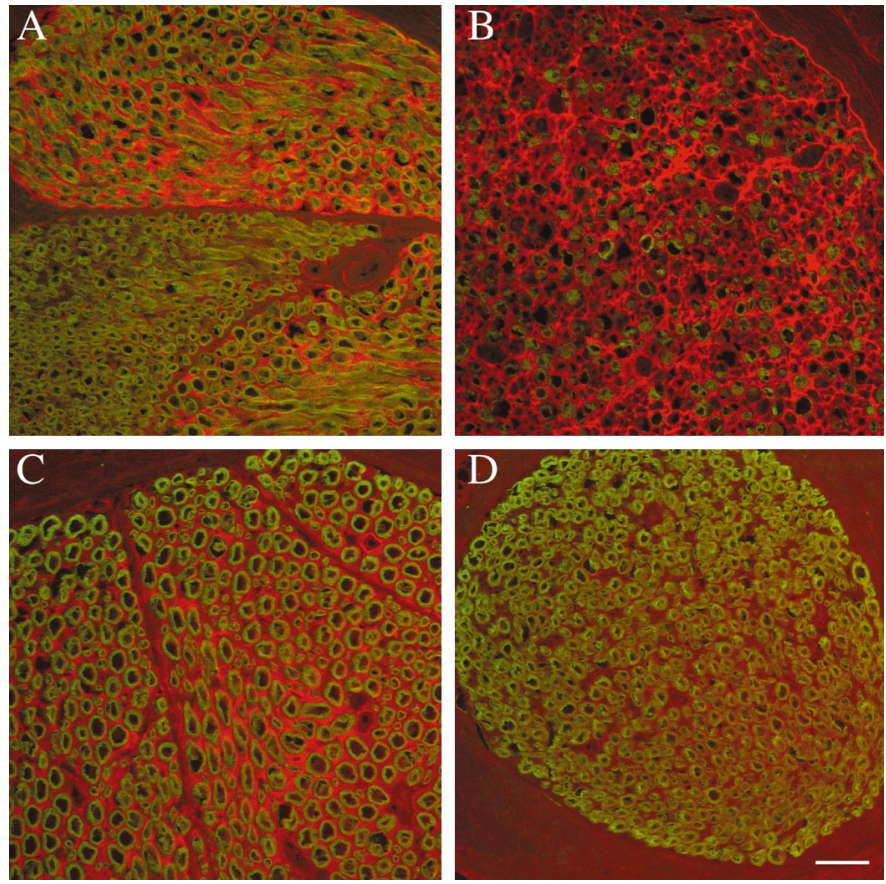

Figure 5. F-spondin immunoreactivity accumulates in the endoneurial ECM after nerve injury. Sections were double-labeled with R5 (TRITC) and myelin basic protein (FITC). Scale bar (shown in $D$ ): $A-D, 10 \mu \mathrm{m} . A$, Transverse section of unlesioned adult rat sciatic nerve. F-spondin immunoreactivity is predominately localized in the ECM of fascicles composed of large myelinated fibers. $B$, Transverse section of an adult rat sciatic nerve $8 \mathrm{~d}$ after axotomy. F-spondin immunoreactivity is seen in the ECM, but at higher levels and in a more uniform distribution (no fascicle-tofascicle variation) than in unlesioned nerve. $C$, Transverse section of unlesioned adult rat femoral motor branch. There is prominent $\mathrm{F}$-spondin immunoreactivity in the ECM associated with the large, myelinated motor fibers. $D$, Transverse section of unlesioned adult rat femoral sensory branch (taken from the same section as $C$ ). The level of F-spondin immunoreactivity is less than that in the motor branch.

region, possibly in a subset of motor neurons that innervate the forelimb (data not shown). The expression of $F$-spondin mRNA along the ventral roots and peripheral nerves was maintained at high levels between E13 and E15 (Fig. 2B-E) and was more intense in the lateral boundaries of the nerve than within the nerve itself (Fig. 2C). No F-spondin mRNA was detected in the dorsal roots at any time, whereas low levels of $F$-spondin mRNA were detected in the DRG and in the ventral horn (Fig. 2D,E). After E15, the level of $F$-spondin mRNA in peripheral nerve declined, so that by birth it was below the level of detection (Klar et al., 1992a).

Because Schwann cells are the predominant cell type along the embryonic peripheral nerve, it is likely that $F$-spondin mRNA is expressed by Schwann cells early in their differentiation and may thus play a role in embryonic axon-Schwann cell interactions. To explore further the interaction between F-spondin protein and the axons, we double-labeled embryonic nerves with the R5 Ab and the monoclonal $\mathrm{Ab} \mathrm{HNK}-1$, which labels nerve fibers and Schwann cells. In E15 rat embryos, F-spondin immunoreactivity was found in the same region as the HNK-1 staining, but also beyond the boundaries of the HNK-1 staining (Fig. 3). Thus, the pattern of F-spondin staining is consistent with an ECM protein located in and around developing peripheral nerves. F-spondin immunoreactivity was not detected at E11 and E13 along the peripheral nerve, perhaps because of the inability of the $\mathrm{Ab}$ to 
$\mathbf{A}$
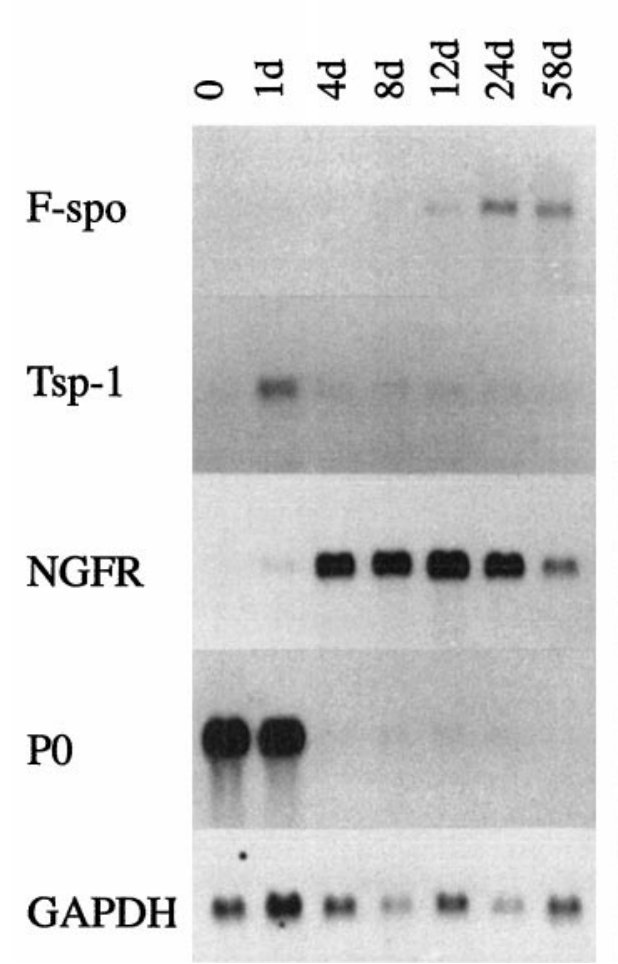

B
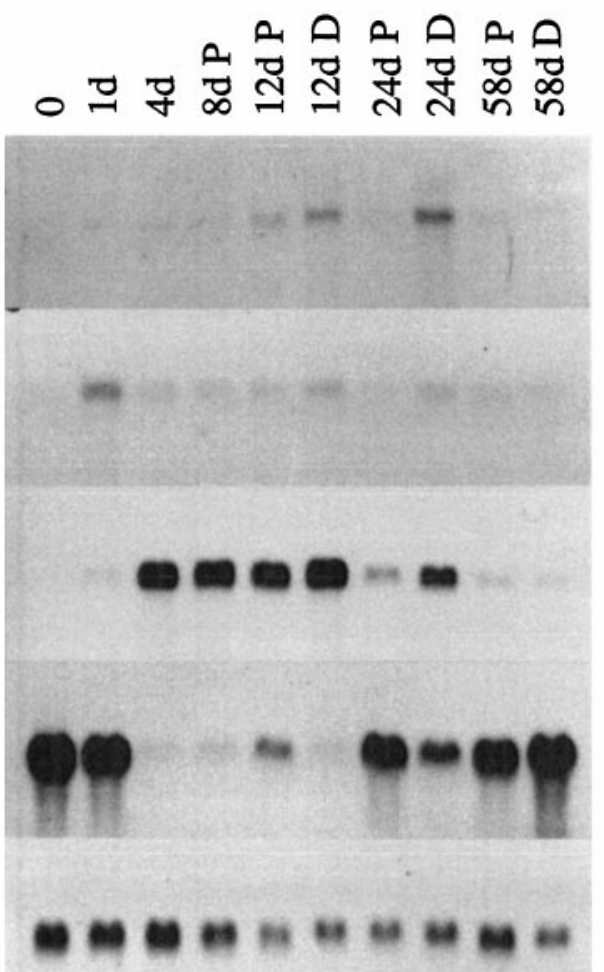

$\mathbf{C}$
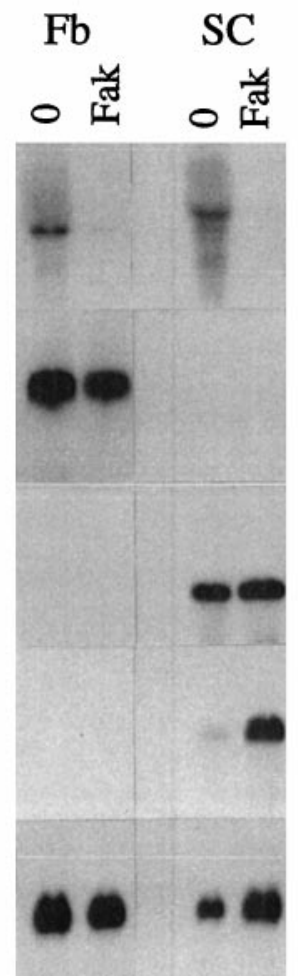

D

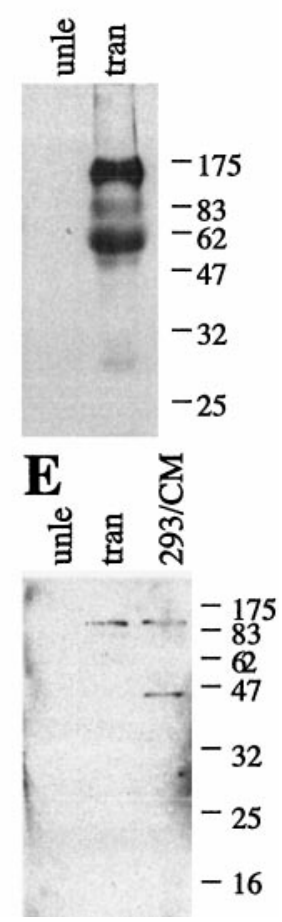

Figure 4. F-spondin mRNA and protein increases in lesioned adult rat sciatic nerve. Each lane in $A-C$ contains an equal amount (10 $\mu$ g) of total RNA isolated from the distal stumps of sciatic nerves that had been transected $(A)$, crushed $(B)$, or cultured Schwann cells and fibroblast $(C)$. The number of days after each of these lesions is indicated; the 0 time point is from unlesioned nerves. The blots were successively hybridized with radiolabeled cDNA probes for F-spondin (F-spo), thrombospondin-1 (Tsp-1), NGFR, $P_{0}$, and GAPDH mRNA and exposed to film for 2 weeks, 2 weeks, $1 \mathrm{~d}$, $2 \mathrm{hr}$, and $3 \mathrm{~d}$, respectively. $B$, The distal nerve stumps were divided into proximal $(P)$ and distal $(D)$ segments of equal lengths. $C$, RNA isolated from fibroblasts $(F b)$ or Schwann cells $(S C)$ cultured for $3 \mathrm{~d}$ in DMEM $+10 \% \mathrm{FCS}$ alone (0), or supplemented with $4 \mu \mathrm{M}$ forskolin (Fak). D, E, Proteins were extracted from unlesioned adult rat sciatic nerves (unle) and the distal stumps of transected (tran) adult sciatic nerves 3 weeks after transection. Each lane contains an equal amount $(4 \mu \mathrm{g})$ of protein extract. $D$, Western blot with the R5 Ab. A 115 and a $60 \mathrm{kDa}$ protein are detected in the injured nerve. E, Western blot with the R2 Ab. A $115 \mathrm{kDa}$ protein is present in the injured nerve, but the $40 \mathrm{kDa}$ protein is not detected (compared with the F-spondin-transfected HEK 293 cells).

detect low levels of the protein. Similarly, no labeling was observed in E15 dorsal root and E11 brachial motor neurons. After birth, the amount of F-spondin staining was reduced but still detectable in the ECM of the endoneurium (see Fig. 5). The timing of mRNA expression, protein localization, and the biological activity of the recombinant F-spondin (Klar et al., 1992a,b) suggest that F-spondin is promoting the outgrowth of the peripheral nerve during development.

\section{F-spondin mRNA is upregulated after nerve injury}

After axotomy, previously myelinating Schwann cells appear to "de-differentiate," because they re-express many proteins that are expressed by premyelinating Schwann cells but are lost as Schwann cells acquire a myelinating phenotype (Scherer and Salzer, 1996). To determine whether F-spondin might be reexpressed with similar dynamics, we examined $F$-spondin mRNA levels distal to a permanent axotomy that was designed to prevent axonal regeneration. As shown in Figure $4 A, F$-spondin mRNA levels increased in a gradual manner between 1 and $24 \mathrm{~d}$ after transection, and they remained elevated until $58 \mathrm{~d}$, the longest time point examined. The increase in $F$-spondin mRNA was more protracted than the increase in the low-affinity NGFR mRNA (Fig. $4 A$ ), which became evident by $4 \mathrm{~d}$ after transection. We compared the upregulation of $F$-spondin mRNA with that of thrombospondin 1 (Tsp-1), which is expressed in peripheral nerve (Hoffman et al., 1994). The level of Tsp-1 mRNA increased after transection, but had a very different time course than that of $F$-spondin, raising to a peak by $1 \mathrm{~d}$ and then declining. Tsp- 1 protein was found to be elevated in regenerating facial motor neurons (Moller et al., 1996), suggesting that the mode of regulation of $T s p-1$ expression after nerve injury is different between facial and sciatic nerve. As expected, the level of $P_{0}$ mRNA, which encodes the major constitutive protein of compact myelin, declined abruptly after axotomy and remained low (Fig. 4A), demonstrating that few, if any, axons were remyelinated.

The above data strongly suggest that the loss of axonal contact results in the upregulation of $F$-spondin mRNA. Because axons regenerate in the PNS, we could test this idea directly by examining $F$-spondin mRNA levels in the distal stumps of crushed nerves, where regeneration occurs, at comparable times to transected (permanently axotomized) nerves. Axons regenerate in a proximal to distal manner, so we subdivided the distal nerve stump into proximal (closest to the lesion) and distal (farthest from the lesion) segments. As shown on Figure $4 B$, the level of $F$-spondin mRNA had decreased in the proximal but not in the distal segment at $24 \mathrm{~d}$ after crush, and in the distal segment at $58 \mathrm{~d}$ after crush. The levels of NGFR mRNA showed a similar 

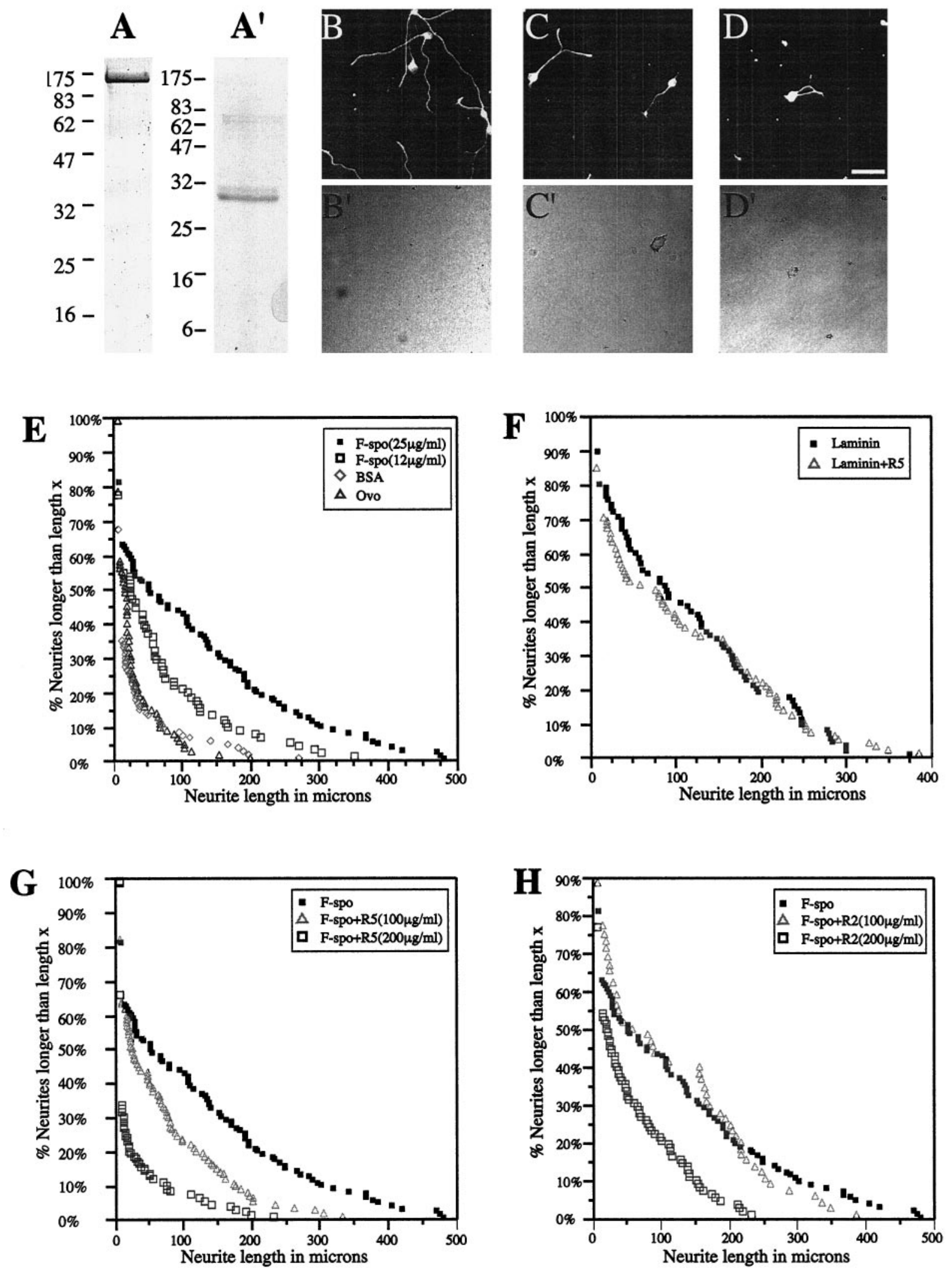

Figure 6. Antibodies against F-spondin inhibit sensory neurite outgrowth on F-spondin-His. F-spondin-His protein $(A)$ and the reelin-His domain protein $\left(A^{\prime}\right)$ were obtained from affinity-purified medium from transfected HEK 293 cells. A single band is observed in a SDS-PAGE gel stained with Coomassie blue (right lane); size markers are shown on the left lane. $B$, Outgrowth on F-spondin-His. $C$, Outgrowth on F-spondin-His with $\mathrm{R} 5$ IgG. $D$, Outgrowth on F-spondin-His with R2 IgG. $B, C$, and $D$ are fluorescence images; $B^{\prime}, C^{\prime}$, and $D^{\prime}$ are phase-contrast images. $E$, Outgrowth on F-spondin-His, BSA, and OVO. F, Outgrowth on laminin and laminin with R5 IgG. G, Outgrowth on F-spondin-His and F-spondin with R5 IgG. $H$, Outgrowth on F-spondin-His and F-spondin with R2 IgG. Neurite outgrowth on F-spondin-His, laminin, BSA, and (Figure legend continues) 
pattern, whereas the levels of $P_{0}$ mRNA had a reciprocal pattern, increasing in the proximal segment at $12 \mathrm{~d}$ after crush and in the distal segment at $24 \mathrm{~d}$ after crush, consistent with the remyelination of regenerated axons. The low levels of $T s p-1$ mRNA, were relatively unchanged between 4 and $58 \mathrm{~d}$. Thus, $F$-spondin mRNA levels are upregulated in vivo after peripheral nerve axotomy, similar to the other genes expressed by embryonic Schwann cells.

To determine which cell types express F-spondin in lesioned nerves, we examined $F$-spondin mRNA expression in Schwann cells and fibroblasts obtained from neonatal sciatic nerves. We also examined the effects of forskolin, a drug that directly activates adenylate cyclase (Seamon et al., 1981), thereby increasing cAMP levels. Elevated cAMP levels mimic some of the effects of axon-Schwann cell interactions (Lemke and Chao, 1988). Schwann cells and fibroblasts expressed comparable amounts of $F$-spondin mRNA, and forskolin decreased the expression in both cell types (Fig. 4C). As reported previously (Lemke and Chao, 1988; Scherer et al., 1994), forskolin increased the level of $P_{O}$ mRNA. This figure also shows that cultured fibroblasts, but not Schwann cells, express Tsp-1 mRNA, but its expression was not regulated by forskolin (Fig. $4 C$ ). These data indicate that both Schwann cells and fibroblasts potentially contribute to the increase in $F$-spondin mRNA after nerve injury.

\section{F-spondin protein is expressed after nerve injury}

To determine whether F-spondin protein expression increases after nerve injury, unlesioned sciatic nerves were obtained from adult rats and distal stumps were obtained from adult rats 3 weeks after sciatic axotomy. The protein fraction was extracted in the presence of protease inhibitors, and equal amounts were blotted and analyzed with the R5 and R2 Abs. In lesioned nerves, the R5 $\mathrm{Ab}$ detected 115 and $60 \mathrm{kDa}$ bands, which correspond to fulllength secreted protein and the reelin/spondin domain, respectively (Fig. 4D). The $60 \mathrm{kDa}$ form is likely to be the result of natural processing, and not a proteolytic artifact, because similar bands were observed even when the tissue was dissected directly into $1 \times$ Laemmli buffer and immediately processed for Western blotting (data not shown). The R2 Ab, in contrast, detected only the $115 \mathrm{kDa}$ protein; the $40 \mathrm{kDa}$ protein was absent (Fig. $4 E$ ). Although neither antibody appears to detect F-spondin protein in unlesioned nerves (Fig. 4D,E), prolonged exposure of these blots revealed 115 and $60 \mathrm{kDa}$ bands with the $\mathrm{R} 5 \mathrm{Ab}$, and a $115 \mathrm{kDa}$ band with the $\mathrm{R} 2 \mathrm{Ab}$. These results demonstrate that the amount of F-spondin protein increases substantially after axotomy. The full-length protein appears to be secreted, and the reelin/spondin domain may accumulate in the ECM, whereas the TSR domain may be released from the ECM or further degraded.

To examine the distribution of F-spondin protein in the unlesioned and lesioned nerves, we immunolabeled sections of unlesioned adult rat sciatic nerve and the distal nerve stumps at 4,8 , 12 , and $24 \mathrm{~d}$ after permanent axotomy. We used different fixatives and embedding agents, but the R2 Ab did not work under any condition tested. The R5 Ab worked well on tissue fixed in Bouin's fluid and embedded in paraffin. To better illustrate the pattern of F-spondin staining, we combined the R5 antiserum with monoclonal antibodies against $\mathrm{P}_{0}$ or myelin basic protein. In unlesioned adult nerves, F-spondin immunoreactivity was in the endoneurial ECM and was higher in nerve fascicles that contained large myelinated fibers (Fig. $5 A$ ). Because the large myelinated fibers are motor fibers and the small diameter fibers are sensory fibers, this pattern suggested that motor fascicles contained more F-spondin than did sensory fascicles. To determine whether this was the case, we stained the femoral nerve, which contains distinct motor and sensory branches, as well as the nerve roots of adult rats DRGs. The ECM of the femoral motor branch (Fig. 5C) was stained more intensely than that of the sensory branch (Fig. $5 D$ ), and the ventral roots had more immunoreactivity than the dorsal roots (data not shown). The observation that F-spondin is relatively enriched in motor nerves may relate to previous findings regarding the selective growth of some kinds of PNS axons on nerve substrates. Motor axons preferentially reinnervate motor nerves (Brushart, 1993), and motor neurons cultured on cryosections of ventral root have longer neurites than those cultured on cryosections of dorsal roots (Martini et al., 1992). The selective growth of motor axons has been related to the expression of the HNK-1/L2 carbohydrate epitope by myelinating Schwann cells of motor but not sensory axons (Martini et al., 1992, 1994). Thus, F-spondin expression could also account for these findings.

After axotomy, F-spondin staining increased markedly by $8 \mathrm{~d}$ after lesion and remained elevated for at least 3 weeks. In contrast to its fascicular distribution (in the ECM of motor but not sensory fibers) in unlesioned adult sciatic nerves, after injury, F-spondin immunoreactivity could be visualized throughout the endoneurium of both the sensory and the motor bundles (Fig. 5B). These data indicate that Schwann cells associated with motor axons have more F-spondin than those associated with sensory axons, but that this difference is masked by the massive increase in F-spondin after axotomy.

\section{$\mathrm{Ab}$ against the spondin domain inhibits neurite outgrowth}

Having established that F-spondin is present in the ECM of lesioned peripheral nerves, we wished to determine whether it plays a role in promoting axonal regeneration. To improve the purification of recombinant F-spondin, we introduced a His-tag at amino acid 753, thereby truncating the sixth TSR repeat and yielding a $110 \mathrm{kDa}$ protein. The $110 \mathrm{kDa}$ protein was secreted, but unlike wild type F-spondin, it was not processed by transfected HEK 293 cells into the reelin/spondin and TSR domains (data not shown). We also tried adding the His tag at the $\mathrm{C}$ terminus of F-spondin, but this prevented the release of F-spondin into the medium of transfected HEK 293 cells (data not shown).

To generate substrates of recombinant F-spondin-His protein, conditioned medium of transfected HEK 293 cells was affinitypurified (Fig. 6A) and immobilized onto nitrocellulose (Lemmon et al., 1989). Laminin, BSA, and OVO substrates were similarly prepared. A suspension of single E14 DRG neurons was plated onto these substrates, and neurite outgrowth was measured after $14 \mathrm{hr}$. As shown in Figure 6, F-spondin-His promoted significantly greater outgrowth than BSA or OVO (Fig. 6B,E; Table 1),

$\leftarrow$

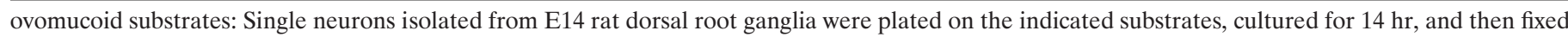

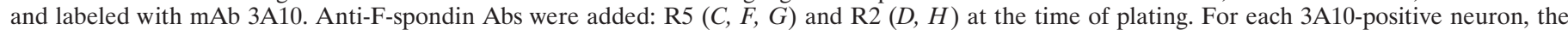

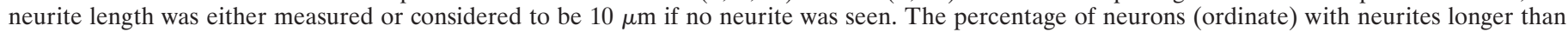
a given length (in micrometers; abscissa) is plotted $(E-H)$. Scale bar: $B-D, 50 \mu \mathrm{m}$. 


\begin{tabular}{|c|c|c|c|c|c|c|c|}
\hline Experiment & Protein & Total cells & Cells with neurites & Mean & Median & $\mathrm{SD}$ & $p$ value \\
\hline \multirow[t]{3}{*}{$\mathrm{E}$} & BSA & 105 & 37 & 65 & 35 & 64 & \\
\hline & F-spo $(12 \mu \mathrm{g} / \mathrm{ml})$ & 90 & 50 & 103 & 72 & 83 & $<0.0001$ \\
\hline & F-spo $(25 \mu \mathrm{g} / \mathrm{ml})$ & 117 & 75 & 173 & 153 & 125 & \\
\hline \multirow[t]{2}{*}{$\mathrm{F}$} & Laminin & 82 & 67 & 135 & 128 & 91 & \\
\hline & Laminin + R5 & 94 & 67 & 142 & 131 & 97 & 0.714 \\
\hline \multirow[t]{3}{*}{ G } & F-spo $(25 \mu \mathrm{g} / \mathrm{ml})$ & 117 & 75 & 173 & 153 & 125 & \\
\hline & $+\mathrm{R} 5(100 \mu \mathrm{g} / \mathrm{ml})$ & 113 & 73 & 94 & 75 & 77 & $<0.0001$ \\
\hline & $+\mathrm{R} 5(200 \mu \mathrm{g} / \mathrm{ml})$ & 134 & 45 & 61 & 34 & 60 & \\
\hline \multirow[t]{3}{*}{$\mathrm{H}$} & F-spo $(25 \mu \mathrm{g} / \mathrm{ml})$ & 117 & 75 & 173 & 153 & 125 & \\
\hline & $+\mathrm{R} 2(100 \mu \mathrm{g} / \mathrm{ml})$ & 125 & 98 & 141 & 158 & 104 & $0.0006^{a}$ \\
\hline & $+\mathrm{R} 2(200 \mu \mathrm{g} / \mathrm{ml})$ & 106 & 58 & 89 & 71 & 61 & \\
\hline
\end{tabular}

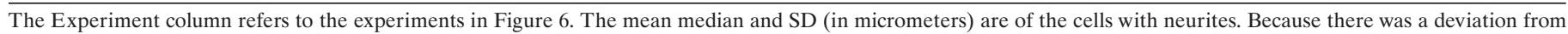

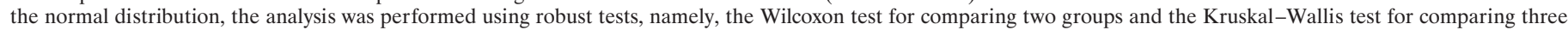
groups (Siegal, 1956). $p$ value $<0.05$ implies a significant difference among the populations within an experiment.

${ }^{a}$ F-spo $(25 \mu \mathrm{g} / \mathrm{ml})$ and $+\mathrm{R} 2(100 \mu \mathrm{g} / \mathrm{ml})$ are not significantly different after adjustment for multiple comparisons.

comparable to the extent of neurite growth on laminin (Fig. $6 F$ ), which is well known for its neurite outgrowth-promoting activity (Baron Van Evercooren et al., 1982). Furthermore, the response was dose-dependent, with $25 \mu \mathrm{g} / \mathrm{ml}$ of F-spondin-His being more potent than $12 \mu \mathrm{g} / \mathrm{ml}$ (Fig. $6 E$; Table 1 ).

We next examined the ability of the R2 and R5 Abs to block the neurite outgrowth-promoting activity of F-spondin. Purified antiF-spondin IgG was added to the medium at the time of plating, and the neurons were cultured for $14 \mathrm{hr}$. As shown in Figure $6 C, G, 100 \mu \mathrm{g} / \mathrm{ml}$ of $\mathrm{R} 5 \mathrm{IgG}$ reduced the mean neurite length by $\sim 50 \% ; 200 \mu \mathrm{g} / \mathrm{ml}$ reduced the mean length by $\sim 70 \%$ (Table 1 ). R2 IgG was less potent: $100 \mu \mathrm{g} / \mathrm{ml}$ had no effect, and $200 \mu \mathrm{g} / \mathrm{ml}$ reduced the mean length by $\sim 50 \%$ (Fig. $6 D, H$; Table 1 ). This inhibitory effect was specific for F-spondin, because $200 \mu \mathrm{g} / \mathrm{ml}$ of either R2 or R5 IgG did not inhibit neurite outgrowth on 20 $\mu \mathrm{g} / \mathrm{ml}$ laminin (Fig. $6 F$ ) (R2 data not shown). These observations demonstrate that antibodies raised against the spondin domain specifically inhibit neurite outgrowth of embryonic sensory neurons. Whether the spondin domain is a more potent substrate than the reelin or TSR domains remains to be determined; several other possible explanations could account for the relatively weaker effect of the R2 Ab (see Discussion).

The ability of F-spondin-His to promote the adhesion of DRG cells was also examined. The number of DRG cells that adhered to F-spondin-His within $60 \mathrm{~min}$ was significantly greater than that to BSA. Addition of the R5 or R2 Abs reduced the number of adherent cells by only $20 \%$ (data not shown). The inability of these Abs to block adhesion may be a result of their lack of recognition of important adhesion domains such as TSR 1 and 2 and the reelin domain. To test this hypothesis, the reelin domain (aa 1-206), was expressed and purified from HEK 293 cells (Fig. $\left.6 A^{\prime}\right)$ and was used in the adhesion assay. The number of DRG neurons that adhered to reelin-His was significantly greater than that to BSA, and $\sim 50 \%$ of the number of cells that adhered to F-spondin-His (data not shown). Thus, the inability of the R2 and R5 to block the adhesion activity of F-spondin might be accounted for the adhesive properties of the reelin domain and TSRs 1 and 2, which are not recognized by the Abs. The cumulative data of the outgrowth and adhesion blocking experiments suggest that the adhesion domains of F-spondin are more widespread than the outgrowth-promoting domains.

To test for the possible involvement of F-spondin in nerve regeneration in vivo, we explanted E14 DRGs on cryostat sections of lesioned adult rat sciatic nerves (Covault et al., 1987; Sandrock and Matthew, 1987; Tuttle and Matthew, 1991; Bedi et al., 1992). Purified IgG of preimmune serum or anti F-spondin antibodies (R5 or R2) were added, and neurite outgrowth was measured after 48 hr. As shown in Figure 7, neurites that extended in the presence of R5 IgG (Fig. 7B) were shorter and tended to fasciculate, compared with neurites grown in the presence of preimmune IgG (Fig. $7 A$ ) or $100 \mu \mathrm{g} / \mathrm{ml} \mathrm{R} 2 \mathrm{IgG}$ (data not shown). To quantitate these differences, the neurites were stained with the anti-neurofilament mAb-3A10, and the total stained area (minus the ganglion) was measured. These results are shown in Figure $7 E$.

Because DRGs express low levels of F-spondin (Fig. 2B,D), we also tested the possibility that they may produce sufficient F-spondin to support neurite outgrowth. Using this same quantitative approach, we found similar neurite outgrowth when DRGs were cultured in three-dimensional collagen gel, treated with preimmune (Fig. 7C) or R5 IgG (Fig. 7D) (analyzed by the Wilcoxon test. No significant difference between the two populations; $p$ value $=0.564, n=6$ ). Likewise, the extension on substrate of unlesioned sciatic nerve was unaffected by the R5 IgG (data not shown). These data indicate that F-spondin promotes neurite outgrowth, thereby supporting the hypothesis that F-spondin participates in axonal regeneration in lesioned peripheral nerves.

\section{DISCUSSION}

In this study, we have demonstrated that F-spondin is expressed by Schwann cells during early development and after peripheral nerve axotomy. Both full-length F-spondin and a $60 \mathrm{kDa}$ fragment containing the reelin/spondin domain accumulate at high levels in the endoneurial ECM after nerve injury. Moreover, highly purified recombinant F-spondin is an excellent substrate for neurite outgrowth, and antibody perturbation assays indicate that F-spondin contributes to axonal regeneration in peripheral nerve.

\section{Structure-function features of F-spondin}

F-spondin is composed of reelin, spondin, and TSR domains, all of which have features that are potentially relevant to axonal regeneration. Reelin is an ECM molecule that is essential for the migration of cortical neuroblasts (D'Arcangelo et al., 1995; Del 

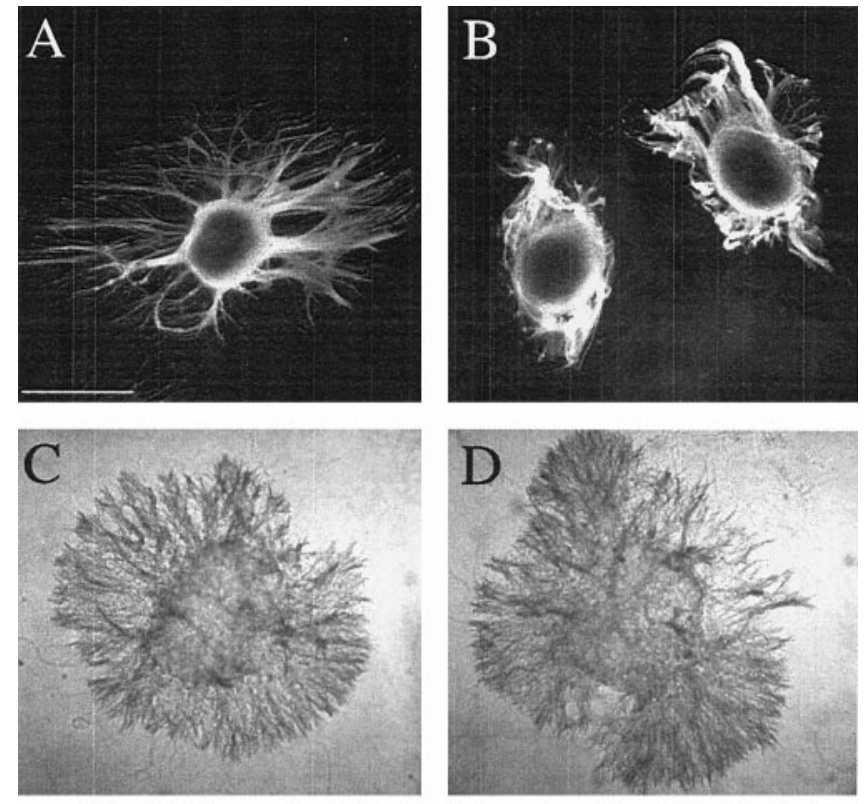

E

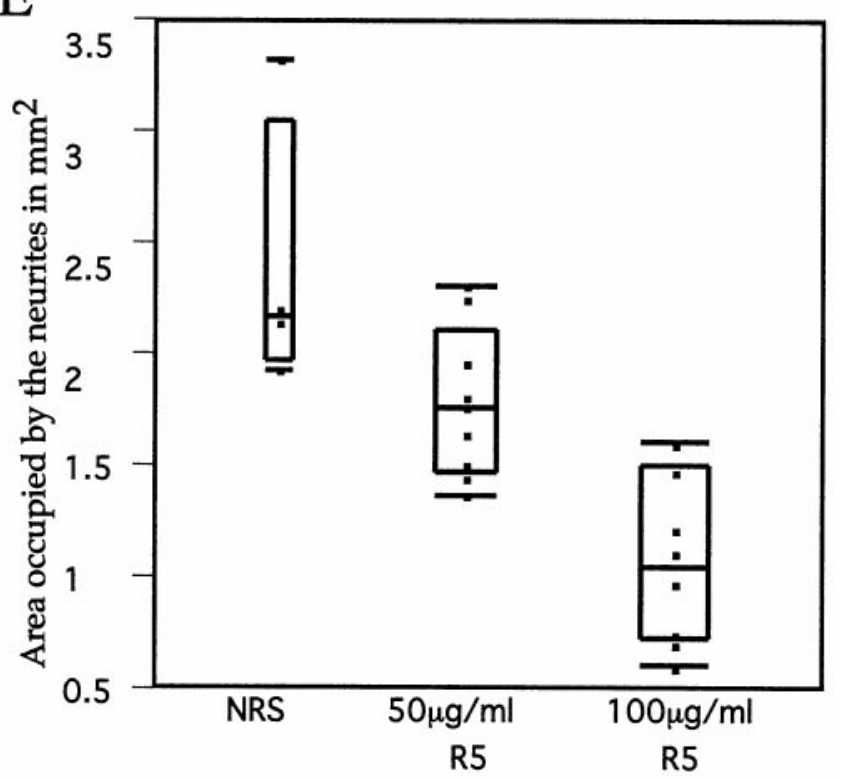

Figure 7. Antibodies against the spondin domain inhibit sensory neurite outgrowth on axotomized sciatic nerve. $A, B$, E14 DRG ganglia were cultured on cryosections of lesioned adult rat sciatic nerve ( 3 weeks after axotomy) for $48 \mathrm{hr}$ with either preimmune serum $(A)$ or $100 \mu \mathrm{g} / \mathrm{ml} \mathrm{R} 5$ immunoglobulin $(B)$. Note that the addition of R5 immunoglobulin results in the tighter grouping of neurites and reduces the extent of neurite outgrowth from the explant. $C, D$, E14 DRG ganglia were cultured in a three-dimensional collagen gel for $24 \mathrm{hr}$. The extent of neurite outgrowth with $100 \mu \mathrm{g} / \mathrm{ml} \mathrm{R5} \operatorname{IgG}(D)$ or with preimmune $\mathrm{Ab}(C)$ is similar. $E$, Summary plot of the effect of R5 immunoglobulin on neurite outgrowth on cryosections of axotomized sciatic nerve. Each dot represents the area occupied by the neurites emerging from one DRG. The boxes enclose $50 \%$ of the results; the horizontal lines above and under the box enclose $90 \%$ of the results; the horizontal line within the box is the median. The difference among the groups was assessed via the KruskalWallis test (Siegal, 1956), which was statistically significant ( $p$ value $<0.001)$.
Rio et al., 1997; Schiffmann et al., 1997), although how reelin acts in this regard remains to be determined. The reelin domain of the rat F-spondin and the amino terminus of mouse reelin are $26 \%$ identical. The conservation between the chick (T. Cohen-Burstyn and A. Klar, unpublished observations), frog (Klar et al., 1992b; Ruiz-I-Altaba et al., 1993), zebrafish [Higashijima et al. (1997); Y. Feinstein and A. Klar, unpublished observations), and Caenorhabditis elegans (Wilson et al., 1994) F-spondins and mouse reelin (20-24\%) provide further support for the presumed functional importance of this domain in F-spondin.

The spondin domain is shared by M-spondin and the mindin genes, which together define a new gene family, the mindins. All are localized in the ECM and contain at least one TSR domain. M-spondin protein is localized at Drosophila muscle attachment sites (Umemiya et al., 1997), and mindins are expressed in the floor plate of zebrafish (Higashijima et al., 1997). The R5 Ab, which recognizes the spondin domain, demonstrated that both the full-length and the processed $60 \mathrm{kDa} F$-spondin proteins were present in axotomized nerve, but we could not establish whether the 115 or the $60 \mathrm{kDa}$ protein or both were the immunoreactive species in immunohistochemistry. However, the ability of R5 Ab to inhibit the neurite outgrowth-promoting activity of substrates of F-spondin and cryosections of degenerating peripheral nerve suggests that the spondin domain is active in promoting outgrowth of sensory neurons.

Until the present study, the TSR domain of F-spondin was thought to be responsible for its outgrowth-promoting activity (Klar et al., 1992a,b). This was based on studies on other TSR domain-containing proteins, such as thrombospondin (Neugebauer et al., 1991; O'Shea et al., 1991; Prater et al., 1991) and malarial circumsporozoite (CR) protein (Rich et al., 1990), which demonstrated that this domain is required for adhesion (CR), and sufficient to promote neurite outgrowth (thrombospondin). The TSR domain is also present in several ligands and receptors that mediate axonal repulsion - the semaphorins F and G (Adams et al., 1996) and the netrin receptor unc-5 (Leung Hagesteijn et al., 1992; Ackerman et al., 1997; Leonardo et al., 1997)—but the role of the TSR domain in these molecules has not been demonstrated. Although our results indicate that antibodies against the TSR domain are relatively ineffective at blocking F-spondin activity, we have not ruled out the possibilities that the R2 Ab might not block the native form of the protein, or alternatively, that the TSR repeats 1 and 2, which were not included in the peptide used to make R2, might be sufficient to promote outgrowth.

\section{The role of F-spondin in promoting axonal regeneration}

Denervated Schwann cells express various cell adhesion molecules, including NCAM, L1, and N-cadherin, as well as the extracellular matrix proteins tenascin-C and F-spondin (Scherer and Salzer, 1996). In addition, the basal laminae of Schwann cells, which persist after injury, contain laminin 2, types IV and VI collagen, heparan sulfate and chondroitin sulfate proteoglycans, fibronectin, and entactin/nidogen (Bunge, 1993; Patton et al., 1997). Furthermore, like other CAMs and ECM components that form macromolecular adhesive complexes, F-spondin might also complex with other molecules, because it can bind to heparan sulfate and chondroitin sulfate (Klar et al., 1992a).

To determine whether F-spondin contributes to axonal regeneration in injured nerve, we used the cryosections of lesioned nerve as a substrate for neurite outgrowth (Tuttle and Matthew, 1991). We show here that antibodies against F-spondin partially 
inhibit neurite outgrowth. Using similar experimental approaches, it was determined that antibodies against $\beta 1$ integrins inhibit neurite outgrowth on sections of normal and lesioned nerves, whereas antibodies that react with laminin 2 inhibit neurite outgrowth on lesioned nerve, and antibodies against fibronectin have no effect (Agius et al., 1996) The axonal receptor for F-spondin could be the integrin $\alpha 3 \beta 1$, the neuronal receptor of Tsp-1 (DeFreitas et al., 1995), if this receptor interacts with the domain that is homologous to F-spondin, the TSR repeats.

The multitude of CAMs in denervated nerve has made it difficult to determine which ones play essential roles in promoting axonal regeneration (Scherer and Salzer, 1996). One approach has been to analyze neurite outgrowth on cultured Schwann cells in the presence of blocking antibodies. These results indicate that $\mathrm{N}$-cadherin, L1, and ligands of $\beta 1$-containing integrins, but not N-CAM, are important (Tomaselli et al., 1986; Bixby et al., 1988; Seilheimer and Schachner, 1988). Similar antibody perturbations in vivo indicate that laminin, fibronectin, N-CAM, tenascin-C, and ligands of $\beta 1$-containing integrins may be important substrates for regenerating PNS axons (Toyota et al., 1990; Mege et al., 1992; Wang et al., 1992a,b; Langenfeld-Oster et al., 1994). In contrast, the analysis of axonal regeneration in the peripheral nerves in N-CAM and tenascin-C-null mice have not revealed any impairment (Forsberg et al., 1996; Moscoso et al., 1998), presumably because of the redundancy of CAMs in lesioned nerves. F-spondin as an extracellular matrix protein that accumulates in the endoneurial ECM after axotomy is likely to play an important role in nerve regeneration. Antibody perturbation experiments in vivo and the analysis of the null mutant will help unravel the role of $\mathrm{F}$-spondin in nerve regeneration.

\section{REFERENCES}

Ackerman SL, Kozak LP, Przyborski SA, Rund LA, Boyer BB, Knowles BB (1997) The mouse rostral cerebellar malformation gene encodes an UNC-5-like protein. Nature 386:838-842.

Adams RH, Betz H, Puschel AW (1996) A novel class of murine semaphorins with homology to thrombospondin is differentially expressed during early embryogenesis. Mech Dev 57:33-45.

Agius E, Sagot Y, Duprat AM, Cochard P (1996) Antibodies directed against the beta 1-integrin subunit and peptides containing the IKVAV sequence of laminin perturb neurite outgrowth of peripheral neurons on immature spinal cord substrata. Neuroscience 71:773-786.

Baron Van Evercooren A, Kleinman HK, Ohno S, Marangos P, Schwartz JP, Dubois Dalcq ME (1982) Nerve growth factor, laminin, and fibronectin promote neurite growth in human fetal sensory ganglia cultures. J Neurosci Res 8:179-193.

Bedi KS, Winter J, Berry M, Cohen J (1992) Adult rat dorsal root ganglion neurons extend neurites on predegenerated but not on normal peripheral nerves in vitro. Eur J Neurosci 4:193-200.

Bixby JL, Lilien J, Reichardt LF (1988) Identification of the major proteins that promote neuronal process outgrowth on Schwann cells in vitro. J Cell Biol 107:353-361.

Bornstein P, O'Rourke K, Wikstrom K, Wolf FW, Katz R, Li P, Dixit VM (1991) A second, expressed thrombospondin gene (Thbs2) exists in the mouse genome. J Biol Chem 266:12821-12824.

Brockes JP, Fields P, Raff MC (1979) Studies on cultured rat Schwann cells. I. Establishment of purified populations from cultures of peripheral nerve. Brain Res:165:105-118.

Brockes JP, Lemke GE, Balzer Jr DR (1980) Purification and preliminary characterization of a glial growth factor from the bovine pituitary. J Biol Chem 255:8374-8377.

Brushart TME (1993) Motor axons preferentially reinnervate motor pathways. J Neurosci 13:2730-2738.

Bunge MB (1993) Schwann cell regulation of extracellular matrix biosynthesis and assembly. In: Peripheral neuropathy (Dyck PJ, Thomas PK, Low PA, Poduslo JF, eds), pp 299-316. Philadelphia: W. B. Saunders.

Chirgwin JM, Przbyla AE, MacDonald RJ, Rutter RJ (1979) Isolation of biologically active ribonucleic acid from sources enriched in ribonuclease. Biochemistry 18:5294-5299.

Covault J, Cunningham JM, Sanes JR (1987) Neurite outgrowth on cryostat sections of innervated and denervated skeletal muscle. J Cell Biol 105:2479-2488.

D'Arcangelo G, Miao GG, Chen SC, Soares HD, Morgan JI, Curran T (1995) A protein related to extracellular matrix proteins deleted in the mouse mutant reeler. Nature 374:719-723.

DeFreitas MF, Yoshida CK, Frazier WA, Mendrick DL, Kypta RM, Reichardt LF (1995) Identification of integrin alpha 3 beta 1 as a neuronal thrombospondin receptor mediating neurite outgrowth. Neuron 15:333-343.

Del Rio JA, Heimrich B, Borrell V, Forster E, Drakew A, Alcantara S, Nakajima K, Miyata T, Ogawa M, Mikoshiba K, Derer P, Frotscher M, Soriano E (1997) A role for Cajal-Retzius cells and reelin in the development of hippocampal connections. Nature 385:70-74.

Fawcett JW, Keynes RJ (1990) Peripheral nerve regeneration. Annu Rev Neurosci 13:43-60.

Forsberg E, Hirsch E, Frohlich L, Meyer M, Ekblom P, Aszodi A, Werner S, Fassler R (1996) Skin wounds and severed nerves heal normally in mice lacking tenascin-C. Proc Natl Acad Sci USA 93:6594-6599.

Fort P, Marty L, Piechaczyk M, Sabrouty SE, Dani C, Jeanteur P, Blanchard JM (1985)Various rat adult tissues express only one major mRNA species from the glyceraldehyde-3-phosphate-dehydrogenase multigenic family. Nucleic Acids Res 13:1431-1442.

Furley AJ, Morton SB, Manalo D, Karagogeos D, Dodd J, Jessell TM (1990) The axonal glycoprotein TAG-1 is an immunoglobulin superfamily member with neurite outgrowth-promoting activity. Cell 61:157-170.

Harland RM (1991) In situ hybridization: an improved whole mount method for Xenopus embryos. Methods Cell Biol 36:675-685.

Harlow E, Lane D (1988) Antibodies: A laboratory manual. Cold Spring Harbor, NY: Cold Spring Harbor Laboratory.

Higashijima S, Nose A, Eguchi G, Hotta Y, Okamoto H (1997) Mindin/ F-spondin family: novel ECM proteins expressed in the zebrafish embryonic axis. Dev Biol 192:211-227.

Hoffman JR, Dixit VM, O'Shea KS (1994) Expression of thrombospondin in the adult nervous system. J Comp Neurol 340:126-139.

Karns LR, Ng S-C, Freeman JA, Fishman MC (1987) Cloning of complementary DNA for GAP-43, a neuronal growth-related protein. Science 236:597-600.

Klar A, Baldassare M, Jessell TM (1992a) F-spondin: a gene expressed at high levels in the floor plate encodes a secreted protein that promotes neural cell adhesion and neurite extension. Cell 69:95-110.

Klar A, Jessell TM, Ruiz i Altaba A (1992b) Control of floor plate identity and function in the embryonic nervous system. Cold Spring Harb Symp Quant Biol 57:473-482.

Langenfeld-Oster B, Faissner A, Irintchev A, Wernig A (1994) Polyclonal antibodies against NCAM and tenascin delay endplate reinnervation. J Neurocytol 23:591-604.

Lawler J, Hynes RO (1986) The structure of human thrombospondin, an adhesive glycoprotein with multiple calcium-binding sites and homologies with several different proteins. J Cell Biol 103:1635-1648.

Lemke G, Axel R (1985) Isolation and sequence of a cDNA encoding the major structural protein of peripheral myelin. Cell 40:501-508.

Lemke G, Chao M (1988) Axons regulate Schwann cell expression of the major myelin and NGF receptor genes. Development 102:499-504.

Lemmon V, Farr KL, Lagenaur C (1989) L1 mediated axon outgrowth occurs via a homophilic binding mechanism. Neuron 2:1597-1603.

Leonardo ED, Hinck L, Masu M, Keino Masu K, Ackerman SL, TessierLavigne M (1997) Vertebrate homologues of C. elegans UNC-5 are candidate netrin receptors. Nature 386:833-838.

Leung Hagesteijn C, Spence AM, Stern BD, Z hou Y, Su MW, Hedgecock EM, Culotti JG (1992) UNC-5, a transmembrane protein with immunoglobulin and thrombospondin type 1 domains, guides cell and pioneer axon migrations in C. elegans. Cell 71:289-299.

Martini R, Xin Y, Schmitz B, Schachner M (1992) The L2/HNK-1 carbohydrate epitope is involved in the preferential outgrowth of motor neurons on ventral roots and motor nerves. Eur J Neurosci 4:628-639.

Martini R, Schachner M, Brushart TM (1994) The L2/HNK-1 carbohydrate is preferentially expressed by previously motor axon-associated Schwann cells in reinnervated peripheral nerves. J Neurosci 14:7180-7191.

Mege RM, Nicolet M, Pincon-Raymond M, Murawsky M, Rieger F 
(1992) Cytotactin is involved in synaptogenesis during regeneration of the frog neuromuscular system. Dev Biol 149:381-394.

Moller JC, Klein MA, Haas S, Jones LL, Kreutzberg GW, Raivich G (1996) Regulation of thrombospondin in the regenerating mouse facial motor nucleus. Glia 17:121-132.

Moscoso LM, Cremer H, Sanes JR (1998) Organization and reorganization of neuromuscular junctions in mice lacking neural cell adhesion molecule, tenascin-C, or fibroblast growth factor-5. J Neurosci 18:1465-1477.

Neugebauer KM, Emmett CJ, Venstrom KA, Reichardt LF (1991) Vitronectin and thrombospondin promote retinal neurite outgrowth: developmental regulation and role of integrins. Neuron 6:345-358.

O'Shea KS, Liu L-HJ, Dixit VM (1991) Thrombospondin and a $140 \mathrm{kd}$ fragment promote adhesion and neurite outgrowth from embryonic central and peripheral neurons and from PC12 cells. Neuron 7:231-237.

Patton BL, Miner JH, Chiu AY, Sanes JR (1997) Distribution and function of laminins in the neuromuscular system of developing, adult, and mutant mice. J Cell Biol 139:1507-1521.

Porter S, Clark MB, Glaser L, Bunge RP (1986) Schwann cells stimulated to proliferate in the absence of neurons retain full functional capability. J Neurosci 6:3070-3078.

Prater CA, Plotkin J, Jaye D, Frazier WA (1991) The properdin-like type I repeats of a human thrombospondin contain a cell attachment site. J Cell Biol 112:1031-1040.

Radeke MJ, Misko TP, Hsu C, Herzenberg LA, Shooter EM (1987) Gene transfer and molecular cloning of the rat nerve growth factor receptor. Nature 325:593-597.

Ramon y Cajal S (1928) Degeneration and regeneration of the nervous system (May RM, ed), p 769. Oxford: Oxford UP.

Rich KA, George FW, Law JL, Martin WJ (1990) Cell-adhesive motif in region II of malarial circumsporozoite protein. Science 249: $1574-1577$.

Romijin HJ, Gabets AMMC, Mud MT, Walters PS (1982) Nerve outgrowth, synaptogenesis and bioelectric activating in rat cerebral cortex tissue cultured in serum-free, chemically defined medium. Dev Brain Res 2:583-589.

Ruiz-I-Altaba A, Cox C, Jessell TM, Klar A (1993) Ectopic neural expression of a floor plate marker in frog embryos injected with the midline transcription factor Pintallavis. Proc Natl Acad Sci USA 90:8268-8272.

Sambrook J, Fritsch EF, Maniatis T (1989) Molecular cloning. Cold Spring Harbor, NY: Cold Spring Harbor Press.

Sandrock AW, Matthew WD (1987) Identification of a peripheral nerve neurite growth-promoting activity by development and use of an in vitro bioassay. Proc Natl Acad Sci USA 84:6934-6938.

Scherer SS, Salzer JL (1996) Axon-Schwann cell interactions during peripheral nerve degeneration and regeneration. In: Glial cell development (Jessen KR, Richardson WD, eds), pp 165-196. Oxford, Bios Scientific.

Scherer SS, Xu YT, Roling D, Wrabetz L, Feltri ML, Kamholz J (1994) Expression of growth-associated protein-43 $\mathrm{kDa}$ in Schwann cells is regulated by axon-Schwann cell interactions and cAMP. J Neurosci Res 38:575-589.

Schiffmann SN, Bernier B, Goffinet AM (1997) Reelin mRNA expression during mouse brain development. Eur J Neurosci 9:1055-1071.

Schwab ME (1990) Myelin-associated inhibitors of neurite outgrowth and regeneration in the CNS. Trends Neurosci 13:452-456.

Seamon KB, Padgett W, Daly JW (1981) Forskolin: unique diterpene activator of adenylate cyclase in membranes and in intact cells. Proc Natl Acad Sci USA 78:3363-3367.

Seilheimer B, Schachner M (1988) Studies of adhesion molecules mediating interactions between cells of peripheral nervous system indicate a major role for L1 in mediating sensory neuron outgrowth on Schwann cells in culture. J Cell Biol 107:341-351.

Siegal S (1956) Nonparametric statistics for the behavioral sciences. New York: McGraw-Hill.

Tomaselli KJ, Reichardt LF, Bixby JL (1986) Distinct molecular interactions mediate neuronal process outgrowth on non-neuronal cell surfaces and extracellular matrices. J Cell Biol 103:2659-2692.

Toyota B, Carbonetto S, David S (1990) A dual laminin/collagen receptor acts in peripheral nerve regeneration. Proc Natl Acad Sci USA 87:1319-1322.

Tuttle R, Matthew WD (1991) An in vitro bioassay for neurite growth using cryostat section of nervous tissue as a substratum. J Neurosci Methods 39:193-202.

Umemiya T, Takeichi M, Nose A (1997) M-spondin, a novel ECM protein highly homologous to vertebrate F-spondin, is localized at the muscle attachment sites in the Drosophila embryo. Dev Biol 186:165-176.

Wang GY, Hirai KI, Shimada H (1992a) The role of laminin, a component of Schwann cell basal lamina, in rat sciatic nerve regeneration within antiserum-treated nerve grafts. Brain Res 570:116-125.

Wang GY, Hirai KI, Shimada H, Taji S, Zhong SZ (1992b) Behavior of axons, Schwann cells and perineurial cells in nerve regeneration within transplanted nerve grafts: effects of anti-laminin and anti-fibronectin antisera. Brain Res 583:216-226.

Wilkinson DG, Bailes JA, Champion JE, McMahon AP (1987) A molecular analysis of mouse development from 8 to 10 days post coitum detects changes only in embryonic globin expression. Development 99:493-500.

Wilson R, Ainscough R, Anderson K, Baynes C, Berks M, Bonfield J, Burton J, Connell M, Copsey T, Cooper J, Coulson A, Craxton M, Dear S, Du Z, Durbin R, Favello A, Rgazer A, Fulton L, Gardner A, Green P, Hawkins T, Hillier L, Jier M, Johnston L, Jones M, Kershaw J, Kirsten J, Laisster N, Latreille J, Lightning J, Lloyd C, Mortimore B, O'Callaghan M, Parsons J, Percy C, Rifken L, Roopra A, Saunders D, Shownkeen R, Sims M, Smaldon N, Smith A, Smith M, Sonnhammer E, Standen RS, Thierry-Mieg J, Thomas K, Vaudin M, Vaughan K, Waterston R, Watson A, Weinstock L, Wilkinson-Spraot J, Wohidman $\mathrm{P}$ (1994) 2.2 Mb of contiguous nucleotide sequence from chromosome III of C. elegans. Nature 368:32-38. 